\title{
殺虫剂抵抗性研究への薬物速度論的手法の応用
}

\author{
大 井 正 典 \\ バイエル植物防疫センター

\section{Application of Toxicokinetic Approaches to Insecticide Resistance Studies}

\author{
Masanori OI \\ PF-E/MR, Pflanzenschutzzentrum Monheim, Bayer AG, D-51368 Leverkusen/Bayerwerk, Germany
}

\section{は じめに}

薬物速度論は体内における薬物の挙動，すなわち薬物の 吸収, 組織への分布, 代謝, 排泄等の速度過程を定量的に 評価する方法として，すでに臨床薬理学の分野では学問的 レベルおよび薬物療法への応用の両面で重要な役割を担っ ている. 一方, 昆虫における殺虫剤の効果は殺虫剂と生体 とのさまざまな相互作用の結果生ずるが，このような相互 作用を数量的に表現する方法として薬物速度論的手法の利 用が考えられる。 そこで薬物速度論的手法を殺虫剂抵抗性 研究に応用することによって，1）イエバエのダイアジノン 抵抗性をモデルに, 複数の抵抗性要因が実際に生体内で果 たす役割や相互作用を評価した。その結果, in vitro 実験で は間接的にしか知ることのできなかった抵抗性要因の役割 を，直接 in vivo で評価できるようになった，2）解毒酵素 と作用点などが含まれる単純な数学モデルを用いて殺虫剂 の連合作用が生ずる条件について調べた。このなかでもと くに相乗作用が生ずる条件に着目し，抵抗性を克服できる ような殺虫剤の組合せを効率よくスクリーニングすること が可能であることを示した。これらの研究について以下に 概説する.

殺虫剤抵抗性の薬物速度論的解析：

\section{イエバェのダイアジノン抵抗性をモデルとして}

本研究で用いた八千代系イエバエは，ダイアジノンによ る数回の淘汰の後 $50 \mu \mathrm{g} /$ 早の $\mathrm{LD}_{50}$ を示し, 感受性系統と 比較して抵抗性比が 1400 倍というきわめて高いもので あった. ${ }^{14} \mathrm{C}$-ダイアジノンを用いた in vitro 実験により，千 トクローム P450依存性モ)オキシゲナーゼ系（チトク
ロームP450) およびグルタチオントランスフェラーゼ (GST) がダイアジノンの解毒に関与し，また GST および リン酸トリエステラーゼがダイアゾクソンの解毒に関与し ていた。 また作用点であるアセチルコリンエステラーゼ (AChE) の低感受性も抵抗性に関与していた ${ }^{1)}$.

薬物速度論的解析を行なうのに十分な資料を得るため に，複数の投与方法によってダイアジノンを処理した．ま ず胸部背板にダイアジノンを処理し，代謝ケージである 20 $\mathrm{ml}$ のシンチレーションバイアルにイエバエを入れ, その後 の挙動を調べたところ, 感受性系統と比較して抵抗性系統 では胸部背板からの薬剂の消失が遅かったことから, 皮膚 における薬剤透過性の低下が示唆された。 また抵抗性系統 ではさらに高薬量を処理したが, 高薬量ほど体内へ透過す るダイアジノンの割合が少なくなるという薬量依存性を示 した Fig. 1). 一方胸部背板にダイアジノンを処理した後 のダイアゾクソン量は系統間で明らかな違いを示し, 体内 におけるダイアゾクソン量の違いが抵抗性に大きく貢献し ていることを示唆した (Fig. 2). これらの結果, 抵抗性で は感受性と同程度の AChE を阻害するにははるかに多く の薬量を要した (Fig. 3). またこれらの実験以外にも，ド ライフィルム法により代謝ケージにダイアジノンを処理し た実験を行なったが, この場合もダイアジノンが体内に取 り込まれる速度は抵抗性イエバエで遅く, 皮膚における薬 剂透過性の違いが示唆された ${ }^{22}$.

系統間におけるダイアジノンの挙動を比較するために $\mathrm{AChE}$ の阻害を二次速度式で，その他の速度過程を一次速 度式で近似し, 得られた連立微分方程式と実験結果を用い てコンピュータシミュレーションを行なった。シミュレー ションには MULTI') 基づいて作成された市販のプログ 


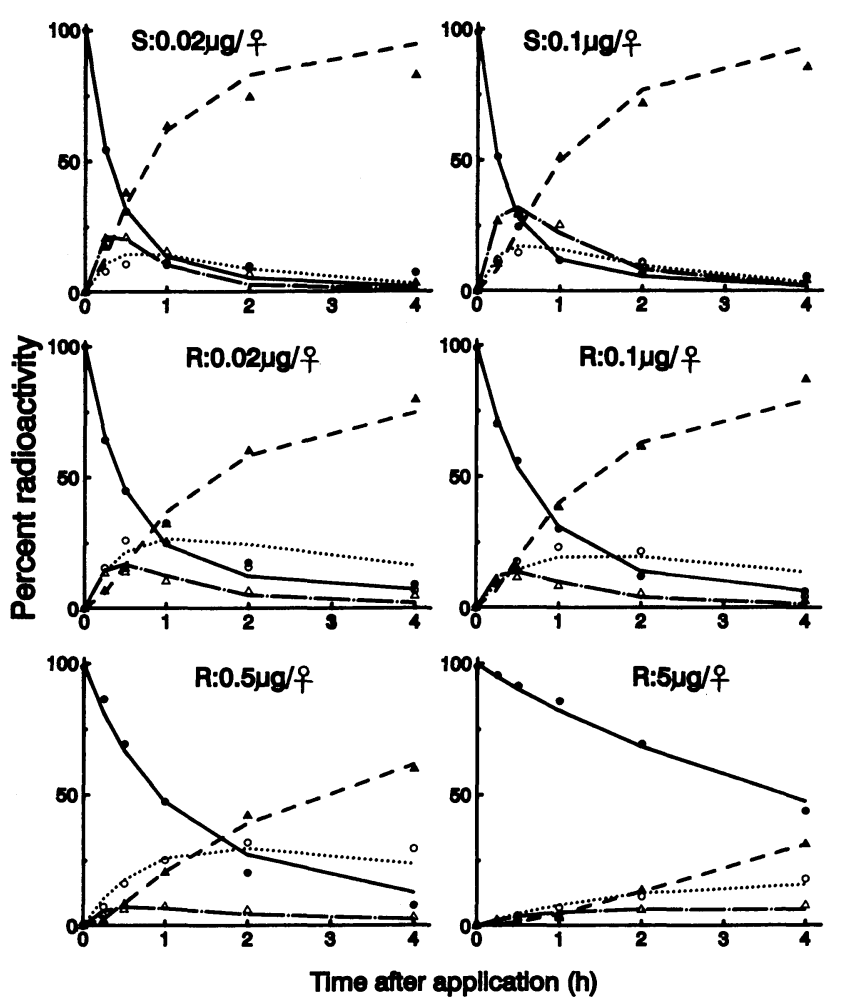

Fig. 1 Distribution of diazinon applied topically to CSMA (S) and Yachiyo (R) strains.

Strains and applied doses are shown in the figures. - : external rinse, $\bigcirc$ : chlorofolm-soluble vial wash, $\triangle$ : chlorofolm-soluble internal extract, $\boldsymbol{\Delta}$ : sum of watersoluble internal extract and excreta. The curves were obtained by computer simulation based on the rate constants. $^{2)}$

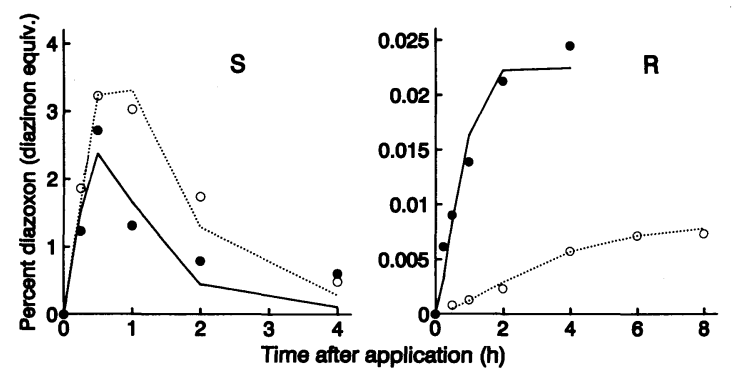

Fig. 2 Time-course of internal diazoxon following topical application of diazinon in CSMA (S) and Yachiyo (R) strains.

Diazinon applied to CSMA strain, $0.02 \mu \mathrm{g} /$ female (๑) and $0.1 \mu \mathrm{g} /$ female $(\bigcirc)$; resistant strain, $5 \mu \mathrm{g} /$ female (๑) and $50 \mu \mathrm{g} /$ female $(\bigcirc)$. The curves were obtained by computer simulation, based on rate constants. ${ }^{2)}$

ラム「マイコンによる薬物体内動態解析法」(南江堂)を用 い，最小二乗法によって実験值との誤差がもっとも少なく なるようなパラメー夕值を算出した. パラメータ值を系統 間で比較したところ, ダイアジノンの透過性に約 2 倍の差

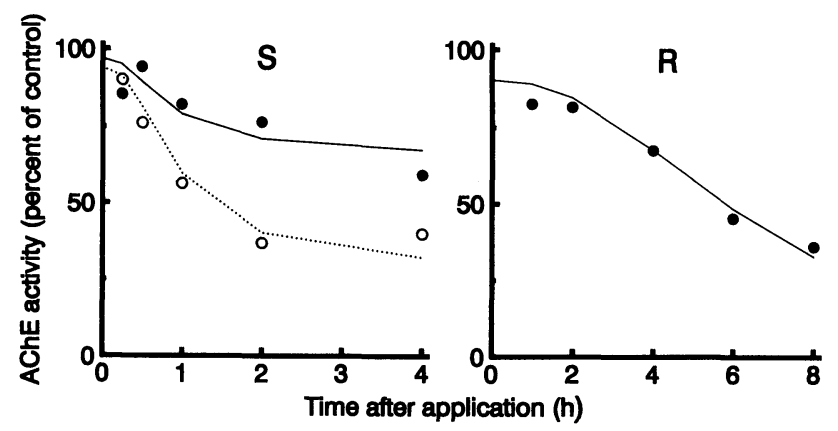

Fig. 3 Time-course of residual AChE activity in the head following topical application of diazinon in CSMA (S) and Yachiyo (R) strains.

Diazinon applied to CSMA strain, $0.02 \mu \mathrm{g} /$ 우 (O) and $0.1 \mu \mathrm{g} /$ 우 $(\bigcirc)$; Yachiyo strain, $50 \mu \mathrm{g} /$ 우. The curves were obtained by computer simulation, based on rate constants. ${ }^{2)}$

があった。また AChEの阻害には 3 倍から 10 倍の差が あった。しかし体内における挙動，とくに抵抗性系統にお けるダイアジノンの活性化とダイアゾクソンの解毒に関し てはおのおののパラメータの誤差が大きく，系統間の比較 が困難であった ${ }^{2)}$.

そこで体内におけるダイアジノンの挙動に関するパラ メータをより正確に求めるため, ダイアジノンおよびダイ アゾクソンを注射投与するという方法をとった. ダイアジ ハンを注射投与したところ，ダイアジノンとダイアゾクソ ンを含むクロロホルム可溶性放射能の極性物質への代謝 (全体の解毒) は抵抗性系統のほうが速かったが, その差は わずかであった．また高薬量ほど代謝の割合が少なくなる という薬量依存性を示した (Fig. 4)。一方，ダイアジノン 注射後のダイアゾクソン量には顕著な差があったので, ダ イアゾクソンを注射投与したところ, ダイアゾクソンの解 毒速度には系統間で明らかな違いが認められ，多イアゾク ソンの解毒の役割が重要であることを示唆した (Fig. 5) ${ }^{4}$.

これらの挙動を系統間で比較するために一次の連立微分 方程式を用いてシミュレーションを行なった，その結果， 全体の解毒のパラメータは 1.5 倍程度の差しかなかった. このクロロホルム可溶性放射能のほとんどはダイアジノン であったことと，多アジノンの消失の多くはダイアゾク ソンを経由しない直接の解毒であることがパラメータの比 較により示唆されたことから, ダイアジノンの解毒の役割 は小さいであろうと推察された. 一方, 薬量や投与方法に よってパラメータの值は異なったものの, ダイアゾクソン の解毒に関しては系統間で 2 倍から 6 倍の差があった。

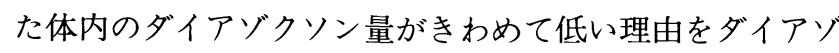
クソンの解毒だけで説明することは不十分で，ダイアゾク ソンへの活性化能の減少も抵抗性に関与していることが示 唆された4). 

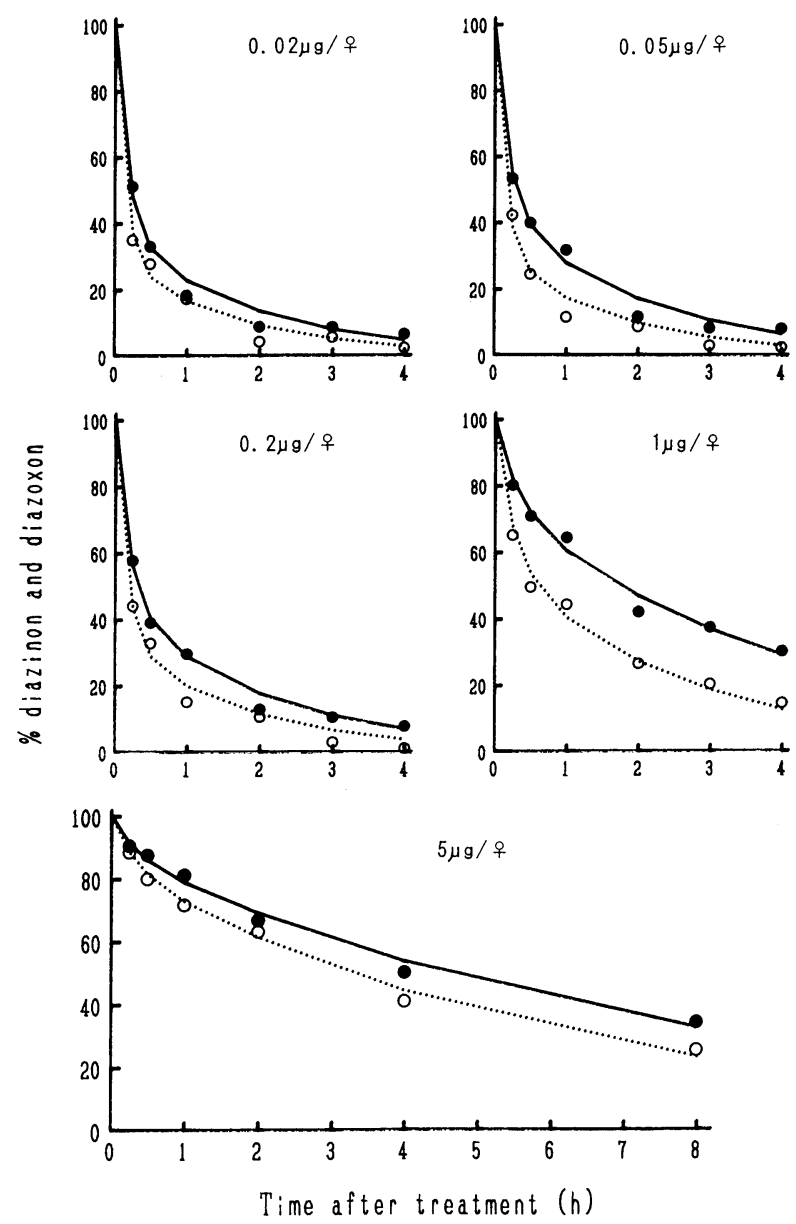

Fig. 4 Degradation of organo-soluble internal radioactivity following injection of various doses of diazinon in CSMA $(\bullet)$ and Yachiyo $(\bigcirc)$ strains.

The curves were obtained by computer simulation, based on the rate constants. ${ }^{4)}$

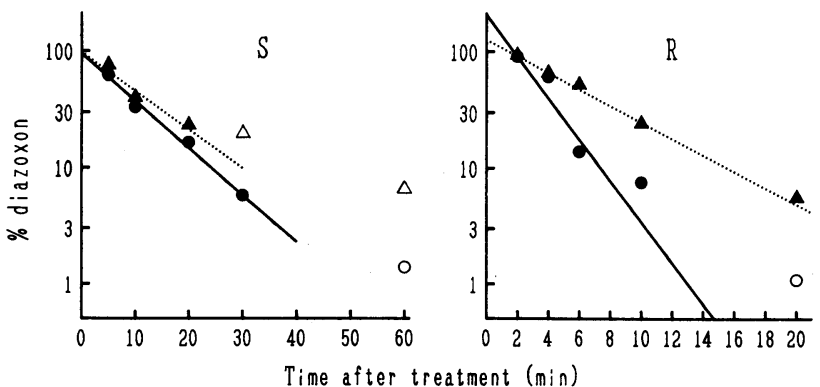

Fig. 5 Percent diazoxon remaining following injection of diazoxon in CSMA (S) and Yachiyo (R) strains.

Applied doses are $0.01 \mu \mathrm{g}$ / 우 $(\mathbf{0}, \bigcirc)$, and $0.1 \mu \mathrm{g}$ / 우 $(\Delta, \triangle)$. The lines were obtained graphically from solid points, based on the rate constants. ${ }^{4)}$

以上のよjに一次の速度式で近似してシミュレーション を行ない，得られたパラメータを系統間で比較することは 簡便な方法といえる。しかし，皮膚における薬剤透過や解

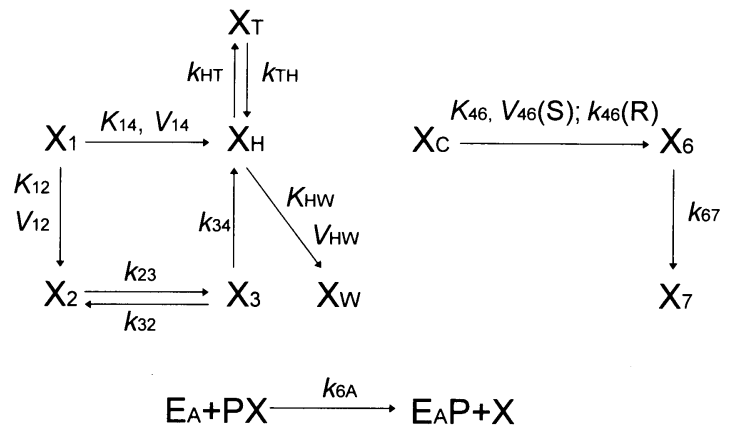

Fig. 6 Kinetic model describing the over-all dynamics of diazinon applied topically.

The model consists of volatilization, cuticular penetration, detoxification of chlorofolm-soluble compounds and activation (S strain) under Michaelis-Menten kinetics, AChE inhibition under second-order reaction and the other processes under apparent first-order kinetics. $\mathrm{X}_{1}$ : diazinon applied on the thorax, $\mathrm{X}_{2}$ : diazinon volatilized in the cage, $X_{3}$ : diazinon picked up by external surface of fly body, $X_{H}$ : diazinon and diazoxon in hemolymph, $X_{T}$ : diazinon and diazoxon distributed to internal tissues, $X_{\mathrm{W}}$ : water-soluble metabolites and excreta, $\mathrm{X}_{\mathrm{C}}=\mathrm{X}_{\mathrm{T}}+\mathrm{X}_{\mathrm{H}}, \mathrm{X}_{6}$ : internal diazoxon, $\mathrm{X}_{7}$ : metabolites of diazoxon, $\mathrm{E}_{\mathrm{A}}$ : $\mathrm{AChE}$, $\mathrm{PX}$ : diazoxon ( $\mathrm{P}$ and $\mathrm{X}$ denote diethyl phosphoric acid moiety and pyrimidine ring, respectively). All parameters and the values are listed in Table 1.

毒などいくつかの速度過程は薬量依存的であり，この場合 薬量によってパラメータの值が異なるため薬量の異なる デー夕を比較することは適切ではない.そこで薬理学の分 野で行なわれた研究5,6)を参考に，抵抗性要因の役割と相互 作用を評価するために以下のような方法論を提案した7). すなわち, 薬量依存性の認められた速度過程には, 酵素レ ベルで用いられる Michaelis-Menten 型の速度式を in vivo でも用いることによって，薬量によってパラメー夕の值が 異なることのないようにした，実験に基づいて得られたダ イアジノンの挙動を示す模式図を Fig. 6 に示すが, この模 式図から得られる速度式は以下のようになる。

$$
\begin{aligned}
d \mathrm{X}_{1} / d t= & -V_{12} \cdot \mathrm{X}_{1} /\left(K_{12}+\mathrm{X}_{1}\right) \\
& -V_{14} \cdot \mathrm{X}_{1} /\left(K_{14}+\mathrm{X}_{1}\right) \\
d \mathrm{X}_{2} / d t= & V_{12} \mathrm{X}_{1} /\left(K_{12}+\mathrm{X}_{1}\right)-k_{23} \mathrm{X}_{2}+k_{32} \mathrm{X}_{3} \\
d \mathrm{X}_{3} / d t= & k_{23} \mathrm{X}_{2}-\left(k_{32}+k_{34}\right) \mathrm{X}_{3} \\
d \mathrm{X}_{\mathrm{H}} / d t= & V_{14} \mathrm{X}_{1} /\left(K_{14}+\mathrm{X}_{1}\right)+k_{34} \mathrm{X}_{3}-k_{\mathrm{HT}} \mathrm{X}_{\mathrm{H}} \\
& +k_{\mathrm{TH}} \mathrm{X}_{\mathrm{T}}-V_{\mathrm{HW}} \mathrm{X}_{\mathrm{H}} /\left(K_{\mathrm{HW}}+\mathrm{X}_{\mathrm{H}}\right) \\
d \mathrm{X}_{\mathrm{W}} / d t= & V_{\mathrm{HW}} \mathrm{X}_{\mathrm{H}} /\left(K_{\mathrm{HW}}+\mathrm{X}_{\mathrm{H}}\right) \\
d \mathrm{X}_{\mathrm{T}} / d t= & k_{\mathrm{HT}} \mathrm{X}_{\mathrm{H}}-k_{\mathrm{TH}} \mathrm{X}_{\mathrm{T}} \\
\mathrm{X}_{\mathrm{C}}=\mathrm{X}_{\mathrm{H}} & +\mathrm{X}_{\mathrm{T}} \\
d \mathrm{X}_{6} / d t= & V_{46} \mathrm{X}_{\mathrm{C}} /\left(K_{46}+\mathrm{X}_{\mathrm{C}}\right)-k_{67} \mathrm{X}_{6} \quad(\mathrm{~S} \text { strain }) \\
d \mathrm{X}_{6} / d t= & k_{46} \mathrm{X}_{\mathrm{C}}-k_{67} \mathrm{X}_{6} \quad(\mathrm{R} \text { strain })
\end{aligned}
$$




$$
\begin{aligned}
& d \mathrm{X}_{7} / d t=k_{67} \mathrm{X}_{6} \\
& d \mathrm{E}_{\mathrm{A}} / d t=k_{6 \mathrm{~A}} \mathrm{X}_{6} \mathrm{E}_{\mathrm{A}}
\end{aligned}
$$

以上の式はかなり複雑であるが，実際には体内における 解毒のパラメータの算出にはダイアジノンの注射投与の データを用いるなど，なるべくモデルを小さくすることに よって上記の式の一部を用いてシミュレーションを行な い，パラメータの誤差を少なくした.シミュレーションに は複数の薬量のデー夕を同時に用いることによって $\mathrm{Mi}$ chaelis 定数 $(K)$ および最大解毒速度 $(V)$ を求めた。薬量 依存性の認められなかった速度過程のパラメー夕には一次 速度式を用いて得られた值の平均値を用いるなどした。こ のようにして得られた值を Table 1 に示す.これらのパラ メータの一部は仮定に基づく值であるが，シミュレーショ ンによって得られる予測値は実験值と大きく異なることは なかった. Table 1 のパラメータを薬剤が体内に透過するま で (透過), 全体の解毒, 活性化, ダイアゾクソンの解毒, $\mathrm{AChE}$ の阻害の五つの速度過程に分け，感受性または抵抗 性のいずれかのパラメータを速度式に代入することによ $\eta$, 合計 32 通りの組合せで一定量の AChE を阻害するの に必要なダイアジノン量を算出した (Table 2)，単独の要因 の場合にはダイアゾクソンの解毒分解能の増大，ダイアゾ クソンへの活性化能の減少, AChEの低感受性が主要因 で，皮䖉の透過性の低下，全体の解毒の働きは小さいこと が示された.さらにこれらの要因の組合せの効果について 調べたところ，たとえば単独での役割の大きかったダイア ゾクソンの解毒分解能の増大, ダイアゾクソンへの活性化

Table 1 Kinetic parameters for the model given in Fig. 6.

\begin{tabular}{lccc}
\hline \multirow{2}{*}{ Pathway } & Parameter & \multicolumn{2}{c}{ Parameter value } \\
\cline { 2 - 4 } & $K_{12}$ & 0.662 & $\mathrm{R}$ \\
\hline & $V_{12}$ & 0.495 & 0.662 \\
& $K_{14}$ & 0.315 & 0.495 \\
Penetration & $V_{14}$ & 0.634 & 0.314 \\
& $k_{23}$ & 1.11 & 0.606 \\
& $k_{32}$ & 1.04 & 0.917 \\
& $k_{34}$ & 1.52 & 0.706 \\
\hline \multirow{3}{*}{ Over all } & $k_{\mathrm{HT}}$ & 1.75 & 1.75 \\
detoxification & $k_{\mathrm{TH}}$ & 0.806 & 0.806 \\
& $K_{\mathrm{HW}}$ & 0.135 & 0.225 \\
& $V_{\mathrm{HW}}$ & 0.515 & 1.19 \\
\hline \multirow{2}{*}{ Activation } & $K_{46}$ & 0.562 & $\mathrm{~N} . \mathrm{D}$. \\
& $V_{46}$ & 0.383 & $\mathrm{~N} . \mathrm{D}$. \\
& $k_{46}$ & $\mathrm{~N} . \mathrm{D}$. & 0.104 \\
\hline Diazoxon detox. & $k_{67}$ & 4.84 & 31.9 \\
\hline AChE inhibition & $k_{6 \mathrm{~A}}$ & 178 & 53.5 \\
\hline Units of $k, K, V$ and $k_{6 \mathrm{~A}}$ are $\mathrm{hr}^{-1}, \mu \mathrm{g}, \mu \mathrm{g} / \mathrm{hr}$ and $\mu \mathrm{g}^{-1} \cdot \mathrm{hr}^{-1}$, \\
respectively. N.D. : not determined. &
\end{tabular}

Table 2 Predicted dose of diazinon, inhibiting 50\% AChE activity in vivo $4 \mathrm{hr}$ after topical application, determined by computer simulation using the rate constants listed in Table 1 for the model given in Fig. 6 .

\begin{tabular}{cc|cc}
\hline Mechanism $^{\mathrm{a})}$ & $\mathrm{I}_{50}$ & Mechanism & $\mathrm{I}_{50}$ \\
$(1 ; 2 ; 3 ; 4 ; 5)$ & $(\mu \mathrm{g} /$ + $)$ & $(1 ; 2 ; 3 ; 4 ; 5)$ & $(\mu \mathrm{g} /$ + $)$ \\
\hline+++++ & $\infty$ & ++++- & $\infty$ \\
-++++ & $\infty$ & -+++- & 2.11 \\
+-+++ & $\infty$ & +-++- & 4.35 \\
--+++ & $\infty$ & --++- & 1.27 \\
++-++ & $\infty$ & ++-+- & 0.562 \\
-+-++ & 1.52 & -+-+- & 0.384 \\
+--++ & 1.99 & +--+- & 0.392 \\
---++ & 0.960 & ---+- & 0.272 \\
+++-+ & 2.55 & +++-- & 0.526 \\
-++-+ & 1.12 & -++-- & 0.357 \\
+-+-+ & 1.29 & +-+-- & 0.370 \\
--+-+ & 0.732 & --+-- & 0.254 \\
++--+ & 0.273 & ++--- & 0.0783 \\
-+--+ & 0.195 & -+--- & 0.0581 \\
+---+ & 0.198 & +---- & 0.0579 \\
----+ & 0.142 & ----- & 0.0433
\end{tabular}

a) Mechanisms 1, 2, 3, 4 and 5 denote penetration, over all detoxification, activation, diazoxon detoxification and AChE inhibition, respectively.

能の減少, AChEの低感受性の要因が組み合わさった場合 には 4 時間後に $50 \%$ の AChE を阻害することは不可能に なった.もちろん 24 時間後までシミュレーションを行なっ た場合には，50\%の AChE を阻害する薬量を算出すること は可能であるが，言い換えれば一定量の AChE を阻害する のにより多くの時間を要するということがいえる。このよ うな条件下では AChEの脱リン酸化も無視できない可能 性がある。また，ダイアゾクソンが低濃度のまま推移する ので AChE を阻害できる有効な濃度になかなか達しない といったことも考えられる。これらの時間的要因も抵抗性 の要因が相乗的に働く原因になると推察される。

\section{殺虫凰の連合作用に関する研究}

殺虫剂の連合作用が発揮される理論的条件を探索するた めに，単一の酵素による解毒と作用点 (AChE) の阻害など が含まれる単純なモデルを用いコンピュータシミュレー ションを行なっだ).

以下のスキーム (a)において，阻害剤が E，ESまたはそ の両方のどれに結合するかによって，それぞれ拮抗阻害 (competitive inhibition), 不拮抗阻害 (uncompetitive inhibition) および非拮抗阻害 (noncompetitive inhibition) の三 つのタイプに分けられる。このなかで異物代謝の研究上重 要9)な拮抗阻害と非拮抗阻害を仮定し，解毒速度に与える 薬剂の組合せの効果を調べた。 

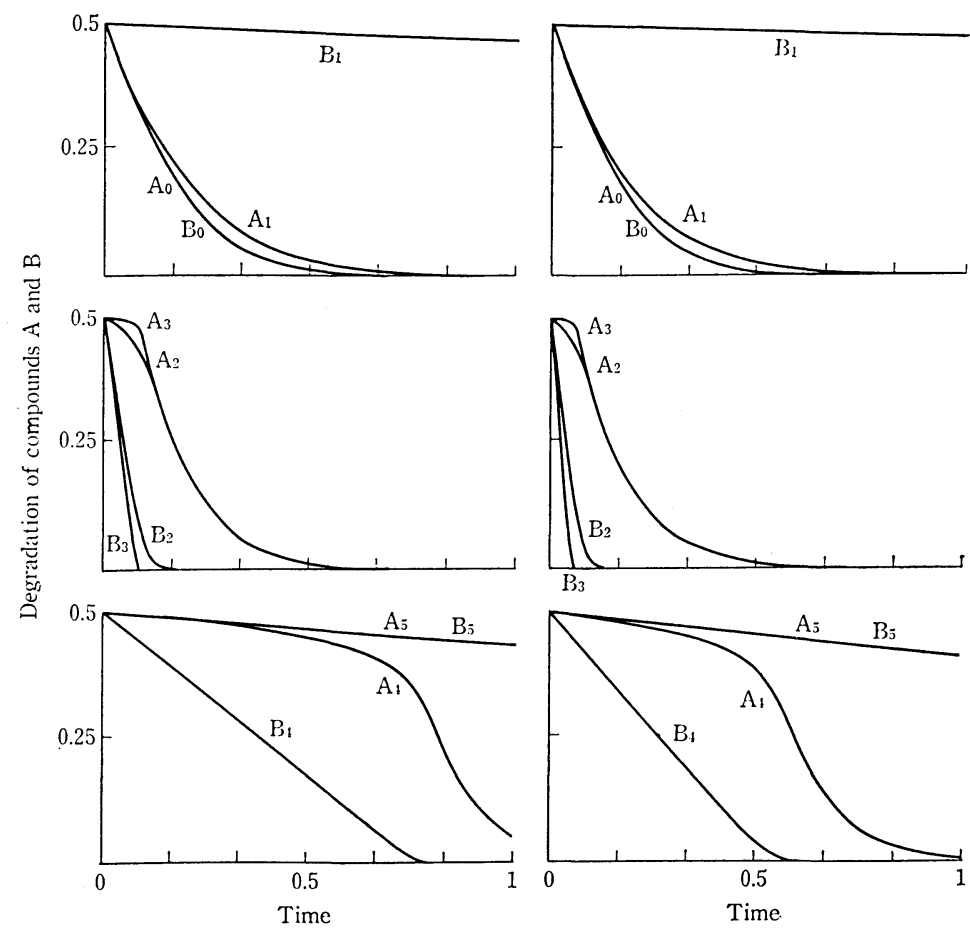

Fig. 7 Effect of combination of two compounds (A and B) on degradation process of each compound, assuming competitive inhibition (right) and noncompetitive inhibition (left).

For competitive and noncompetitive inhibition Eqs. (2-1) and (2-2), as well as (2-3) and (2-4) given in the text were used, respectively. Curves $\mathrm{A}_{0}$ to $\mathrm{A}_{5}$ and $\mathrm{B}_{0}$ to $\mathrm{B}_{5}$ indicate degradation process of compounds $\mathrm{A}$ and $\mathrm{B}$, respectively. Parameter values of $K_{\mathrm{A}}, V_{\mathrm{A}}, K_{\mathrm{B}}$ and $V_{\mathrm{B}}$ used for computation were, respectively, 1, 10, 1 and 10 for $\mathrm{A}_{0}$ and $\mathrm{B}_{0} ; 1,10,1$ and 0.1 for $\mathrm{A}_{1}$ and $\mathrm{B}_{1} ; 1,10,0.1$ and 10 for $\mathrm{A}_{2}$ and $\mathrm{B}_{2} ; 1,10,0.01$ and 10 for $\mathrm{A}_{3}$ and $\mathrm{B}_{3} ; 1,10,0.01$ and 1 for $\mathrm{A}_{4}$ and $\mathrm{B}_{4} ; 1,10,0.01$ and 0.1 for $A_{5}$ and $B_{5}$.

$$
\mathrm{E}+\mathrm{S} \rightleftarrows \mathrm{ES} \longrightarrow \mathrm{E}+\mathrm{P}
$$

$\mathrm{E}$ : enzyme, $\mathrm{S}$ : substrate, $\mathrm{P}$ : product

薬剤 $\mathrm{A}$ と B の解毒にかかわる酵素が一つであるとすれ ば, 二つの阻害様式によって得られる速度式は以下のよう になる。

$$
\begin{aligned}
d[\mathrm{~A}] / d t= & -V_{\mathrm{A}}[\mathrm{A}] /\left\{[\mathrm{A}]+\left(1+[\mathrm{B}] / K_{\mathrm{B}}\right) K_{\mathrm{A}}\right\} \\
d[\mathrm{~B}] / d t= & -V_{\mathrm{B}}[\mathrm{B}] /\left\{[\mathrm{B}]+\left(1+[\mathrm{A}] / K_{\mathrm{A}}\right) K_{\mathrm{B}}\right\} \\
d[\mathrm{~A}] / d t= & -V_{\mathrm{A}}[\mathrm{A}] /\left\{\left(1+[\mathrm{B}] / K_{\mathrm{B}}\right)[\mathrm{A}]\right. \\
& \left.+\left(1+[\mathrm{B}] / K_{\mathrm{B}}\right) K_{\mathrm{A}}\right\} \\
d[\mathrm{~B}] / d t= & -V_{\mathrm{B}}[\mathrm{B}] /\left\{\left(1+[\mathrm{A}] / K_{\mathrm{A}}\right)[\mathrm{B}]\right. \\
& \left.+\left(1+[\mathrm{A}] / K_{\mathrm{A}}\right) K_{\mathrm{B}}\right\}
\end{aligned}
$$

式 (2-1) と式 (2-2) は拮抗的阻害を, 式 (2-3) と式 (2-4) は非拮抗的阻害を仮定した場合の式である。ここで，[A]

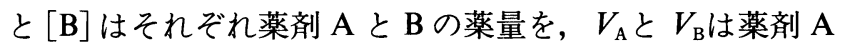
と B それぞれの最大解毒速度を， $K_{\mathrm{A}}$ と $K_{\mathrm{B}}$ はそれぞれの Michaelis 定数を示す.

以上の (2-1) 〜 (2-4) 式に各パラメー夕值を与えたときの 薬剂 A と B の消失を Fig. 7 に示すが，たとえば $K_{\mathrm{A}}, V_{\mathrm{A}}$, $K_{\mathrm{B}}, V_{\mathrm{B}}$ をそれぞれ $1,10,0.01 ， 1$ とした場合， $\mathrm{A}_{4}$ と $\mathrm{B}_{4}$ の
ような消失の曲線となり, いずれの阻害様式も薬剂 B が存 在している間は薬剤 $\mathrm{A}$ の解毒は起こりにくくなる.このと き薬剂 $\mathrm{B}$ と比較して薬剤 A が作用点に対する阻害力の大 きい薬剤であれば高い相乗作用となる.

$\mathrm{AChE}$ 阻害に関する以下の式 (2-5) および薬剤が単独の 場合の速度式を加之, Sun \& Johnson の協力係数 ${ }^{10)}$ を指標 にし, 連合作用が生ずる条件について調べた結果, 連合作 用のなかでもとくに相乗作用に関して以下のような一般的 性質が明らかになった。

$$
d[\mathrm{E}] / d t=-\left(k_{\mathrm{A}}[\mathrm{A}]+k_{\mathrm{B}}[\mathrm{B}]\right)[\mathrm{E}]
$$

なお， E は薬剤を組み合せた場合の $\mathrm{AChE}$ の残存活性度 を示す.

（1）相乗作用の基本的条件は次の条件が満たされること である.

$$
V_{\mathrm{B}} \ll V_{\mathrm{A}} \mathrm{I}_{\mathrm{B}} / \mathrm{I}_{\mathrm{A}}, \quad K_{\mathrm{B}} \ll K_{\mathrm{A}} \mathrm{I}_{\mathrm{B}} / \mathrm{I}_{\mathrm{A}} \quad \text { かつ } \quad K_{\mathrm{B}} \ll \mathrm{I}_{\mathrm{B}}
$$

なお Iは解毒酵素を含んだ条件で作用点を $50 \%$ 阻害す る薬骭の濃度，すなわち $\mathrm{I}_{50}$ を表す. $\mathrm{I}_{\mathrm{A}}$ が小さく, $V_{\mathrm{A}}$ が大き いほうがこの条件を満たすことから，薬剤 $\mathrm{A} は$ は作用点に対 する阻害能力が大きく，かつ解毒されやすいという条件が 必要である。薬剤 $\mathrm{B}$ は作用点を阻害するのに必要な濃度よ 
りも低濃度で薬剤 $\mathrm{A}$ の解毒を阻害できなければならない。 この条件を満たすほど“相乗作用のポテンシャル”は大き く, 薬剂 B が薬剂 A の解毒酵素を阻害する結果, 薬剂 $\mathrm{A}$ の 濃度が増し作用点の阻害速度を増加させることになる。

（2）相乗作用がもっとも大きくなる薬剂 A と B の混合 比は $\mathrm{I}_{\mathrm{A}}$ と $\mathrm{I}_{\mathrm{B}}$ の比 $\left(\mathrm{LD}_{50}\right.$ の比) に等しい.

以上の理論的解析の結果を証明するために, in vitro 実験 を行なった ${ }^{11)}$. 単一の酵素(ブタ肝カルボキシルエステラー ゼ）（CE）による解毒と作用点 (電気ウナギ AChE) 阻害の みが含まれる単純なモデルを用いて，相乗作用の予測に必 要な各パラメー夕を求めたところ，マラオクソンとジクロ ルボス (Table 3) およびマラオクソンとパラオクソン （Table 4）の組合せがもっとも相乗作用の条件を満たして いた. それぞれの組合せによる AChE 阻害の $\mathrm{I}_{50}$ を比較し たところ，上記の組合せは実際に高い相乗作用を示し，ま た相乗作用のもっとも大きくなる混合比は薬剂単独での $I_{50}$ 值に等しかった. 以上の結果はコンピュータシミュレー ションによる理論的解析の結果を支持した。

上記の理論的解析の結果をもとに，有機りン剂抵抗性イ エバエ八千代系に対して相乗作用をもたらす薬剤の組合せ を殺虫試験のレベルで探索した ${ }^{12)}$. 理論的解析で示した相 乗作用を発揮するために必要な，解毒を阻害される側の梖

Table 3 Effect of the mixing ratio of malaoxon and dichlorvos on the co-toxicity coefficient calculated from $\mathrm{I}_{50}$ for AChE inhibition in the presence of CE.

\begin{tabular}{|c|c|c|c|}
\hline \multicolumn{2}{|c|}{ Ratio } & \multirow{2}{*}{$\begin{array}{l}\mathrm{I}_{50}^{\mathrm{a})} \\
(\mu \mathrm{M})\end{array}$} & \multirow{2}{*}{$\begin{array}{l}\text { Co-toxicity } \\
\text { coefficient }\end{array}$} \\
\hline Malaoxon & Dichlorvos & & \\
\hline 1 & 0 & 25.7 & \\
\hline 1 & 0.01 & 13.9 & 172 \\
\hline 1 & 0.1 & 4.37 & 345 \\
\hline 1 & 0.114 & 2.74 & 523 \\
\hline 1 & 1 & 1.75 & 301 \\
\hline 1 & 10 & 1.92 & 166 \\
\hline 0 & 1 & 2.93 & \\
\hline
\end{tabular}

a) Data expressed as the sum of both inhibitors.

Table 4 Effect of the mixing ratio of malaoxon and paraoxon on the co-toxicity coefficient calculated from $I_{50}$ for AChE inhibition in the presence of CE.

\begin{tabular}{ccccc}
\hline \multicolumn{2}{c}{ Ratio } & & $\begin{array}{c}\mathrm{I}_{50} \text { a) } \\
(\mu \mathrm{M})\end{array}$ & $\begin{array}{c}\text { Co-toxicity } \\
\text { coefficient }\end{array}$ \\
\cline { 1 - 2 } Malaoxon & & Paraoxon & & \\
1 & $\vdots$ & 0 & 25.7 & 198 \\
1 & $\vdots$ & $5.7 \times 10^{-4}$ & 12.7 & 352 \\
1 & $\vdots$ & $5.7 \times 10^{-3}$ & 6.24 & 577 \\
1 & $\vdots$ & $3.22 \times 10^{-2}$ & 2.30 & 529 \\
1 & $\vdots$ & $5.7 \times 10^{-2}$ & 1.85 & 326 \\
1 & $\vdots$ & $5.7 \times 10^{-1}$ & 0.660 & \\
0 & $:$ & 1 & 0.828 &
\end{tabular}

a) Data expressed as the sum of both inhibitors.
剂（薬剂 A）または解毒を阻害する側の薬剤（薬剤 B）の性 質をもつ薬剂のどちらか一方をみつけることができれば， 相乗作用をみつける確率を増すことができるはずである。 そこで最初に薬剤 A の性質, すなわち作用点に対する阻害 能力が大きく，かつ解毒されやすい，という性質をもつ薬 剤を協力剂の効果を指標にしてスクリーニングし，それに 対して相乗作用を発揮する薬剂 B みつけるという方法 をとった，供試昆虫として八千代系イエバエを用い，薬剂 として一連の有機リン剂，カーバメート剂，ピレスロイド 剂を用い，協力剂としてチトクロームP450の阻害剂であ るピペロニルブトキシド $(\mathrm{PBO})^{13)}$ ，チトクローム $\mathrm{P} 450$ と GSTを阻害するとの報告のあるマレイン酸ジエチル $(\mathrm{DEM})^{14)}$ ，リン酸トリエステラーゼを阻害する $\mathrm{DEF}^{15)}$ ，お よびカルボキシルエステラーゼ(16)や GST ${ }^{17)}$ を阻害するこ とが知られているIBP の 4 種を用いた，その結果，協力剤 の効果の高いいくつかの殺虫剤がスクリーニングされた (Table 5).とくにダイアジノンに対しては DEF，カルボフ ランに対してはPBOの効果が高かった。このなかで薬剤 $\mathrm{A}$ の性質をもっていたダイアジノンに対して他の殺虫剤 を組み合わせたところ，いくつかの組合せが相乗作用を示 したが，このなかでもダイアジノンとカルボフランの組合 せはきわめて高い相乗作用を示し，相乗作用のもっとも大 きくなる混合比は $\mathrm{LD}_{50}$ の比に等しかった (Table 6). どち らの薬剂も協力剤の効果が高く薬剤 $\mathrm{A}$ としての性質を もっていたので，相乗作用のメカニズムについて調べたと ころ，まずダイアゾクソンとカルボフランの組合せでは相 乗作用が認められず，またカルボフランはダイアゾクソン の解毒には影響しなかったので，ダイアゾクソンの解毒は ダイアジノンのカルボフランの相乗作用のメカニズムには 関与していないことを示唆した。これとは逆にダイアジノ

Table 5 Effect of several synergists on the toxicity of various insecticides against Yachiyo strain of the housefly.

\begin{tabular}{|c|c|c|c|c|c|c|}
\hline \multirow{3}{*}{ Insecticide } & \multirow{3}{*}{$\begin{array}{c}\text { Dose } \\
\text { applied } \\
(\mu \mathrm{g} / \text { 古 })^{\mathrm{a})}\end{array}$} & \multicolumn{5}{|c|}{ Mortality (\%) } \\
\hline & & \multicolumn{5}{|c|}{ Synergists } \\
\hline & & None & PBO & DEM & DEF & IBP \\
\hline Pirimicarb & 2.15 & 20 & 88 & 23 & 43 & 25 \\
\hline Carbofuran & 4.18 & 23 & 98 & 55 & 75 & 30 \\
\hline Methomyl & 0.0300 & 33 & 13 & 13 & 23 & 23 \\
\hline Propoxur & 2.61 & 10 & 8 & 25 & 43 & 43 \\
\hline Dioxabenzofos & 0.200 & 5 & 0 & 5 & 3 & 0 \\
\hline Dichlorvos & 0.460 & 3 & 3 & 8 & 0 & 0 \\
\hline Acephate & 4.22 & 0 & 23 & 3 & 35 & 20 \\
\hline Diazinon & 23.6 & 10 & 5 & 13 & 98 & 30 \\
\hline$d$-Allethrin & 0.885 & 25 & 85 & 18 & 43 & 30 \\
\hline Tetramethrin & 0.751 & 33 & 90 & 43 & 63 & 40 \\
\hline Fenvalerate & 0.0814 & 18 & 78 & 20 & 38 & 20 \\
\hline
\end{tabular}

a) A dose equilivarent to $\mathrm{LD}_{10}$ of each insecticide was applied topically to the thorax at $1 \mathrm{hr}$ after the flies received a synergist $(10 \mu \mathrm{g} /$ o $)$ on the tip of abdomen. 
Table 6 Synergism between diazinon (insecticide A) and the other insecticides (insecticide B) against Yachiyo strain of the housefly.

\begin{tabular}{|c|c|c|c|}
\hline Insecticide B & $\begin{array}{l}\text { Mixing } \\
\text { ratio }^{\text {a) }}\end{array}$ & $\begin{array}{l}\mathrm{LD}_{50} \mathrm{~b}^{\mathrm{C}} \\
(\mu \mathrm{g} / \text { 우 })\end{array}$ & $\begin{array}{l}\text { Co-toxicity } \\
\text { coefficient }\end{array}$ \\
\hline Pirimicarb & 0.107 & 14.2 & 242 \\
\hline \multirow{4}{*}{ Carbofuran } & $0.05^{\mathrm{c})}$ & 3.75 & 1438 \\
\hline & 0.236 & 1.86 & 2067 \\
\hline & $1^{c)}$ & 1.70 & 1399 \\
\hline & $10^{\mathrm{c})}$ & 6.32 & 250 \\
\hline Methomyl & 0.00183 & 22.7 & 137 \\
\hline Propoxur & 0.147 & 8.07 & 442 \\
\hline Dioxabenzofos & 0.00632 & 34.4 & 91 \\
\hline Dichlorvos & 0.0166 & 63.4 & 50 \\
\hline Acephate & 0.185 & 8.62 & 427 \\
\hline$d$-Allethrin & 0.0395 & 45.6 & 71 \\
\hline Tetramethrin & 0.0432 & 12.4 & 263 \\
\hline Fenvalerate & 0.00580 & 17.0 & 184 \\
\hline
\end{tabular}

a) $\mathrm{LD}_{50}$ of $\mathrm{B} / \mathrm{LD}_{50}$ of $\mathrm{A}$.

b) Expressed as the sum of two insecticides mixed.

c) Various ratios were tested to investigate the effect on synergism.

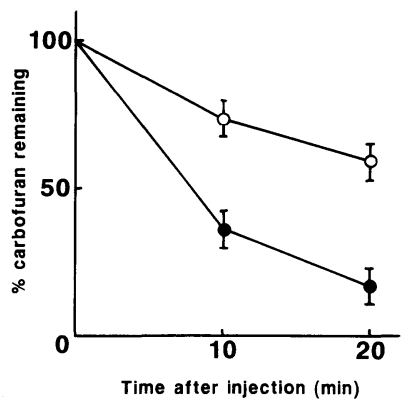

Fig. 8 Effect of diazinon on the degradation of carbofuran in vivo.

Carbofuran at the dose of $0.1 \mu \mathrm{g} /$ 우 was injected to the flies of Yachiyo strain with $(\bigcirc)$ or without $(\bullet) 0.5 \mu \mathrm{g} /$ 우 diazinon.

ンとカルボフランの混合液を注射投与したところ，ダイア ジノンは $\mathrm{LD}_{50}$ (注射投与) 以下の薬量でカルボフランの解 毒を阻害し，カルボフラン消失の一次速度定数は 3.4 倍低 下した (Fig. 8)。さらにin vivoにおいてダイアジノンとカ ルボフランの混合液の処理によって阻害された AChEの 脱アシル化速度 $\left(k_{3}\right)$ と, in vitroにおいてダイアゾクソン またはカルボフランによって阻害された AChEの脱アシ ル化速度を比較したところ, in vitroにおいてダイアゾクソ ンによってリン酸化された AChEは，実験条件下（30 分） では活性の回復がまったく認められなかったのに対して, カルボフランによってカルバミル化された AChE の回復 は速く， $k_{3}$ は 0.0137 であった. 一方，in vivoにおいて夕゙イ アジノンとカルボフランの混合液を処理した後に阻害され た AChEの見かけの $k_{3}$ は脱カルバミル化定数に近く, $k_{3}$ は 0.0109 であったことから, 実際に AChE を阻害しているの
はカルボフランであることが示された。したがって，この 相乗作用の機構は，ダイアジノンがそれ自体では作用点を 阻害しない薬量でカルボフランの解毒を阻害した結果，カ ルボフランの体内濃度が増加し AChE の阻害力を高めた ことによることが明らかとなった。ダイアジノンに関して

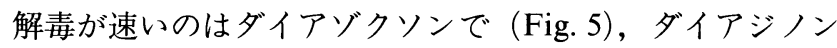
の解毒 (Fig. 4) はカルボフランの解毒 (Fig. 8) よりも遅 いことを考慮すれば，ダイアジノンが解毒を阻害する側の 薬剤 Bだとしても理論的解析から得られた結論と矛盾す ることはない.

なおカルボフランの解毒酵素と考えられるチトクローム P450をダイアジノンが阻害する機構であるが, たとえばパ ラチオンの酸化により生成する硫黄原子がチトクローム P450 に共有結合して失活させることや18)，スルフォニルウ レア系の除草剤の解毒に関与するチトクローム P450をマ

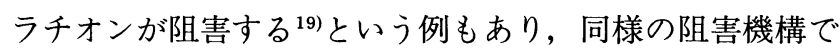
ある可能性が考えられる，殺虫剤抵抗性に関連して，興味 深い今後の研究課題である.

\section{おわりに}

本研究で示したように, in vivoのデー夕を薬物速度論的 手法を用いて解析することによって，昆虫体内における殺 虫剤の挙動をよりダイナミックに表現することができる. また薬物速度論的手法が抵抗性要因の役割や相互作用を評 価するために有用であることを示した．本研究で行なった 解析は市販のプログラムで十分可能であることから，殺虫 剤抵抗性研究の方法論の一つとして利用価值が高いと思わ れる。

殺虫剂の組合せが相乗作用を示す例として，有機リン剤 とカーバメイト剤の組合せなどいくつかの例があるが，実 際にこれらの組合せはウンカ・ヨコバイ類の防除に使用さ れてきた ${ }^{20)}$.しかし実際にはランダムな組合せのなかから， 防除可能な組合せをみつけることは容易ではない，本研究 では協力剤の効果を指標に，既存の薬剤のなかから相乗作 用を示す組合せを効率よくみつけることが可能であること を示した．薬郕の相乗作用を利用した防除方法を，上記の 例に限らずより広範囲に役立てるためにも，本研究で示し た方法は抵抗性害虫の防除法の一つとして利用できるので はないかと思われる。

本研究を行なうにあたりご指導, ご鞭撻いただいた千葉大学 教授, 本山直樹先生（現在, 生態制御化学）に厚くお礼申し上 げます。また, 本研究は環境生物学研究室（当時）の方々の多 くのご協力と有意義な議論を得て行なわれたものであり，あわ せて感謝いたします。

\section{引用文 献}

1) M. Oi, W. C. Dauterman \& N. Motoyama : J. Pesticide Sci. 
15, $217(1990)$

2) M. Oi, W. C. Dauterman \& N. Motoyama : Appl. Entomol. Zool. 27, 371 (1992)

3) K. Yamaoka, Y. Tanigawara, T. Nakagawa \& T. Uno: $J$. Pharmacobio.-Dyn. 4, 879 (1981)

4) M. Oi, W. C. Dauterman \& N. Motoyama : Appl. Entomol. Zool. 28, 59 (1992)

5) G. Levy, T. Tsuchiya \& L. P. Amsel : Clin. Pharmacol. Ther. 13, 258 (1972)

6) E. Nelson, M. Hanano \& G. Levy: J. Pharmacol. Exp. Ther. 153, 159 (1966)

7) 大井正典：千葉大学園芸学部修士論文 (1987)

8) 大井正典・本山直樹：農薬誌 16, 465 (1991)

9) 本山直樹: 毒性生化学, 本山直樹 - 佐藤哲男 編, ソフト サイエンス社, p. 136, 1982

10) Y.P. Sun \& E. R. Johnson: J. Econ. Entomol. 53, 887 (1960)

11) 大井正典・本山直樹：農薬誌 16, 475 (1991)

12) 大井正典・本山直樹：応動昆 35, 231 (1991)

13) J. E. Casida : J. Agric. Food Chem. 18, 753 (1970)

14) W. Welling \& J. W. de Vries : Pestic. Biochem. Physiol. 23,
$358(1985)$

15) L. T. Jao \& J. E. Casida: Pestic. Biochem. Physiol. 4, 465 (1974)

16) R. H. Yang, E. Hodgson \& W. C. Dauterman : J. Agric. Food Chem. 19, 14 (1971)

17) C. L. Yeoh, E. Kuwano \& M. Eto: J. Pesticide Sci. 7, 31 (1982)

18) T. Kamataki \& R. A. Neal : Mol. Pharmacol. 12, 933 (1976)

19) K. Kreus, P. R. Fonne \& P. J. Porpiglia : Plant Physiol. 96, 27 (1991)

20）浜 弘司：害虫はなぜ農薬に強くなるか：薬剤抵抗性の しくみと害虫管理，農文協，p. 160,1992

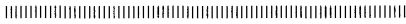

Society Awards 1996

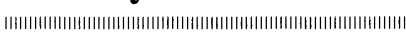

(on high prospectiveness)

\section{Application of Toxicokinetic Approaches to Insecticide Resistance Studies}

\section{INTRODUCTION}

Pharmacokinetics, which evaluate internal dynamics of drugs, e.g. absorption, distribution into internal tissues, metabolism, excretion and so on, play an important role in the field of clinical pharmacology. By applying this approach (toxicokinetics) to insecticide resistance studies, the significance and interaction of resistance factors were evaluated in vivo. This approach was also used to elucidate theoretical conditions which produce potentiation of insecticidal activity. Based on these conditions, one of the methods which overcome resistance by using the potentiation was demonstrated with a resistant housefly.

\section{TOXICOKINETIC APPROACHES TO THE MECHANISMS OF DIAZINON RESISTANCE IN HOUSEFLY}

A housefly colony collected at a sanitary land fill was selected with diazinon for several generations in the laboratory. The resultant strain (Yachiyo strain) was 1400 times more resistant to diazinon $\left(\mathrm{LD}_{50}: 50 \mu \mathrm{g}\right.$ per fly). It had increased activity in each of the three enzyme systems in involved in detoxification. Cytochrome P450-dependent monooxygenases and glutathione transferase (GST) catalyzed diazinon degradation. GST and phosphorotriester hydrolase catalyzed diazoxon degradation. The resistant strain also showed a decreased sensitivity to inhibition of acetylcholinesterase (AChE), at the site of action.

Toxicokinetic analysis was employed to investigate the significance of various factors responsible for resistance in susceptible and resistant strains of housefly to diazinon. Topical application and application by exposure to a residual film of the compound in a holding vial was conducted. Significant differences were observed between the strains in the penetration of diazinon, the amount of diazoxon present, and the degree of $\mathrm{AChE}$ inhibition. Certain $k$ values estimated by computer simulation using the experimental data and linear differential equations derived from the toxicokinetic models proposed for the external and internal dynamics of diazinon demonstrated an inter-strain difference. In particular, the ratio of diazoxon degradation over activation of diazinon was much greater in the resistant strain than in the susceptible strain, suggesting the low accumu- 
lation of diazoxon was the most important resistance factor. Insensitive $\mathrm{AChE}$ also played an important role in vivo.

To investigate the internal dynamics of diazinon more accurately, the effects of diazinon and diazoxon administered by injection were studied. Flies which received diazinon by injection showed only a small interstrain difference in the internal amount of diazinon. In contrast, large interstrain difference was observed in the internal amount of diazoxon when the flies received diazinon or diazoxon by injection. Several kinetic models were postulated and examined to describe the internal dynamics of diazinon. Interstrain comparison of the kinetic parameters estimated by computer simulation revealed that fast degradation of diazoxon played an important role. It is also suggested that fast degradation of diazinon and less activation are responsible for the decreased accumulation of diazoxon.

The above simulation using linear equations was a convenient way to compare the resultant parameters between strains. However, some pathways, e.g. penetration and degradation were dose-dependent processes and the rate constants varied with the dose. Therefore Michaelis-Menten type equation which is used in enzymology was proposed in vivo for the dose-dependent processes. The apparent Michaelis constant and maximum velocity were simulated with experimental data from several doses. The other processes which did not show dose-dependence were approximated with linear equations except for AChE inhibition which was simulated with 2 nd order equation. The differential equations using Michaelis-Menten type equations allowed the following analysis.

The parameters were divided into five processes (mechanisms), i.e. penetration, polarization of organo-soluble diazinon and diazoxon (overall detoxification), activation, detoxification of diazoxon and AChE inhibition. Then the amounts of diazinon which inhibit 50\% AChE four hours after application were calculated for a total of 32 combinations derived from various combinations of each mechanism.

With respect to the individual processes, detoxification of diazoxon, less activation of diazinon and insensitive AChE were the main machanisms, on the other hand penetration and overall detoxification play a minor role. By combining the above three main mechanisms, inhibition of $50 \%$ AChE by diazinon needed more time than four hours. The time-dependent factor also seemed to be important to consider for the synergism of resistance mechanisms.

\section{STUDIES ON JOINT ACTION OF INSECTICIDES}

Theoretical studies were conducted by computer simulation on the condition that a combination of two compounds produces a joint action. A simple model was employed with the main components of a single enzyme for degradation and a site of action for inhibition. Studies were based on the assumption that two compounds inhibit the degradation enzyme either competitively or non-competitively. The following factors governing the joint action of insecticides were elucidated based on the co-toxicity coefficient value :

1. Potentiation appears at $V_{\mathrm{B}} \ll V_{\mathrm{A}} \mathrm{I}_{\mathrm{B}} / \mathrm{I}_{\mathrm{A}}, K_{\mathrm{B}} \ll K_{\mathrm{A}} \mathrm{I}_{\mathrm{B}} /$ $\mathrm{I}_{\mathrm{A}}$ and $K_{\mathrm{B}} \ll \mathrm{I}_{\mathrm{B}}$, where $\mathrm{A}$ and $\mathrm{B}$ denote compounds $\mathrm{A}$ and $B$, and the degradation of each compound is under control of maximum degradation velocity $\left(V_{\mathrm{A}}\right.$ and $\left.V_{\mathrm{B}}\right)$ and Michaelis constant $\left(K_{\mathrm{A}}\right.$ and $\left.K_{\mathrm{B}}\right)$ of the MichaelisMenten type rate equations. $I_{A}$ and $I_{B}$ denote concentrations of compounds $\mathrm{A}$ and $\mathrm{B}$ affording $50 \%$ inhibition of the target in the presence of the degradation process. The situation indicates that compound A should have a high potential to inhibit the target and at the same time should be susceptible to degradation. Compound B should be able to inhibit the degradation of compound A at a lower concentration than required to inhibit the target. The more the properties of compounds A and B fulfill the above condition, the greater the resultant potentiation. With other words, compound B inhibits the degradation of compound A resulting in an increased accumulation of compound $\mathrm{A}$, which in turn leads to a stronger inhibition of the target.

2. Potentiation is maximum when the ratio of compounds $A$ and $B$ is equal to the ratio of $I_{A}$ and $I_{B}$ (this could be substituted for convenience by the ratio of $\mathrm{LD}_{50}$ of the compounds).

To substantiate that the level of potentiation produced by joint action of insecticides could be predicted by using the above parameters, in vitro studies were carried out. The parameter values were determined in a simple model system that consists of only a single enzyme for degradation, i.e. carboxylesterase from porcine liver, and a target for inhibition of AChE from electric eel. The results showed that a combination of malaoxon and paraoxon as well as malaoxon and dichlorvos among various combinations of insecticides evaluated fulfilled the conditions for potentiation in a satisfactory manner. A comparison of $I_{50}$ for AChE inhibition under the conditions of the degradation enzyme involved actually demonstrated a high level of potentiation with the above two combinations. Furthermore, the mixing ratio of the two insecticides which produced the maximum potentiation level was equal to the ratio of $I_{50}$ of the individual insecticides. These results were in agreement with the theoretical analysis by computer simulation.

A toxicity test was conducted in search of a combination of insecticides that is effective against the organophosphorus-resistant, Yachiyo strain of housefly. According to the theoretical results mentioned above, if an insecticide fulfilling the condition of compound A can be screened in advance, the probability to find out a 
combination which produces potentiation would increase. It should be considered that the more fulfill the condition compound A, the more the effect of inhibitor of the degradation enzyme increase. Therefore, some inhibitors were combined with insecticides to find out a compound $\mathrm{A}$ in advance. Some of the insecticides tested fulfilled the condition of compound $\mathrm{A}$, in particular the activity of diazinon is strongly increased in combination with DEF, a phosphorotriester hydrolase inhibitor and carbofuran in combination with PBO, a cytochrome P450 inhibitor. Accordingly, diazinon was combined with a series of insecticides. Remarkable potentiation was exhibited when diazinon was paired with carbofuran. The $\mathrm{LD}_{50}$ values for diazinon, carbofuran and the mixture at the ratio of $\mathrm{LD}_{50}$ were 62.2 , 14.7 and $1.86 \mu \mathrm{g}$ per fly, respectively. The potentiation was greatest when the two compounds were mixed at the ratio of their $L_{50}$. However, diazoxon coupled with carbofuran showed little potentiation. Since carbofuran did not inhibit the degradation of diazoxon, it seems that diazoxon degradation is not involved in the potentiation between diazinon and carbofuran. When a mixture of diazinon and carbofuran was injected into houseflies, diazinon at a concentration below the $\mathrm{LD}_{50}$ inhibited carbofuran degradation, decreasing the first order rate constant 3.4 times for the carbofuran disappearance. A comparison of the rate of deacylation of acylated AChE produced in vivo by application of a mixture of diazinon and carbofuran and that produced in vitro by diazoxon or carbofuran, showed that the in vivo inhibition of AChE is mainly caused by carbofuran. From these results it is reasonable to conclude that the potentiation is attributable to an increase in the internal concentration of carbofuran, which inhibits more AChE, resulting from inhibition of carbofuran degradation by diazinon at sublethal concentrations. 